\title{
Factors Affecting Willingness to Pay for Improved Water Supply System in Rural Tanahu, Nepal
}

\author{
Ananta Raj Dhungana \\ Lecturer of Statistics, Pokhara University \\ Email: anantastat@gmail.com \\ and \\ Basanta Baral
}

\begin{abstract}
This study aims to analyze the factors associated with willingness to pay for improved water supply system in rural Tanahu, Nepal. For this purpose, one hundred and twenty seven households were proportionately distributed among wards 5, 6, 7 \& 8 and selected for data collection. Structured questionnaire was used to collect the data. Chi-square test was used to find the factors associated with willingness to pay for improved water supply system. This study shows that there is no any significant association between willingness to pay for improved water supply system and social, demographic and economic variables. However, water source, dental pain, water quantity, want for change are water fetching time have significant association with willingness to pay for improved water supply system. Cases of Jaundice is significantly associated with willingness to pay for improved water supply system However, there is no significant association between willingness to pay and satisfaction from WUC activities, water purification, diarrhea, dysentery, seasonal flu, and suffering from worm. So, it can be concluded that type of water source, quantity, fetching time, will for change, and prevalence of some disease (Jaundice, Dental Pain) are the major factors influencing willingness to pay for improved water supply system in the study area.
\end{abstract}

Keywords : Factor, improved water supply system, social demographic and economic, willingness to pay

\section{Introduction}

Water is the most essential element for survival of lives in the planet earth. Without water no life would be possible. Water is usually a locationspecific resource and mostly a non tradable output. However rural areas 
in developing countries across the world remain severely underprivileged, with eight out of ten people not having access to safe water supply (WHO and UNICEF, 2006).

Water is not only important for livelihood but also for primary healthcare. Primary healthcare is important for poverty alleviation. Hence water is vital for poverty alleviation. International water policies and management practices have generally considered water to be a free and renewable resource. Governments in developing countries have often subsidized water supplies, typically in an attempt to achieve social and health benefits for low-income households that comprise a large majority of the rural population (Lammerink, 1998; Whittington et al., 1998).

Financing the domestic water supply is important for livelihood of poor. In general, water supply is done publicly under some regulation. In the world, of every 10 people, 2 lack accesses to safe water supply, 5 have inadequate sanitation, and 9 do not have their wastewater treated to any degree (World Bank, 2004).

Briscoe and de Ferranti found that increase in $10 \%$ of $\mathrm{HH}$ income in Zimbabwe raised consumption of water by $4 \%$. In the same line, Calkins found from the study in Mali that the purchasing power of consumer is positively linked to WTP for water. Briscoe and de Ferranti found that women from Zimbabwe were willing to pay $40 \%$ more to water than their husband. They found that these women wanted to invest the surplus time into commercial activities. Briscoe and de Ferranti observed that women with higher level of education in Zimbabwe were to use more clean water and pay more. Similar results were shown by Asthana (1997) in India and Joyasundara et al. (1999) in Bangladesh. Asthana (1997) and Joysundara et al. (1999) reported that higher literacy of women affect the water consumption, source identification, quality and reliability and hence the WTP. In Nepal, Bhandari and Grant (2007) found that amount of consumption of water by the HHs as one of the attributes for WTP. In their study, the analysis showed no significant association between sociodemographic variables and satisfaction of the users. That means gender, age, economic status and education do not affect the one's satisfaction. WTP is affected by the water source point. i.e. WTP differs according to the 
distance of water source point from the $\mathrm{HH}$ of the respondent. Gunatilake and Tachiiri (2012) in Khulna of Bangladesh found that the richer people are more willing to pay for both monthly charges and connection charges. For poor people the connection charge is very high and they wish for volumetric pay for monthly charge instead of flat charges. Estimation model showed the statistically significant variables as follows: Household Expenditure, Dummy variable for $\mathrm{HH}$ with private wells, Dummy variable for $\mathrm{HH}$ with hand-pump tube wells, schooling year of $\mathrm{HH}$ head and $\mathrm{HH}$ expenditure for electricity. WTP was associated with richness of $\mathrm{HH}$, with no private or use of public tube wells, and more educated HH head positively. Wang et al. (2008) in Chogqing of China found a positive relationship between $\mathrm{HH}$ income and WTP. That means $\mathrm{HH}$ with high income showed more WTP than with low income. Similar result was obtained with male respondents. Female respondents are less willing to pay than male. Reminder about inclusion of sewage fee, education, age, monthly consumption of water, satisfaction with current supply system are those variables with no significant effects on WTP. Pour and Kalashami (2012) found that WTP for improved service was higher in urban area than rural of Iran where educational status is also higher. The income level had positive relation with WTP. Water pressure, quantity and dissection were the major reasons for dissatisfaction and use of alternative sources to fulfill the demand is must.

Adeoye et al. (2013) found that women and children are more associated with fetching of water in North Central Nigeria. The considerable water qualities were found to be color, taste, odor and proximity to the residence. Tarfasa (2013) in a study carried out in Ethiopia found that consumption of water at $\mathrm{HH}$ level was found to range from $10 \mathrm{~L}$ to $800 \mathrm{~L}$ per day. Sex of the $\mathrm{HH}$ head, income, the area (zone) of living and HH's aversion behavior are the significant socio-demographic variables. Women prefer improvement in the domestic water supply compared to male $\mathrm{HH}$ heads. Higher the income more was WTP for proposed change. People with lowest income and lowest service found to pay up to 60 percent extra for improvement over the current bill for water. The significant effect was found for averting behavior and expenditures. 
As cited by Ifibiyi(2011); WBDRT (1993) study also showed that household with more educated member were more willing to pay. In the same vein, Briscoe and de Ferranti observed that women with higher level of education in Zimbabwe were to use more clean water and pay more. Similar results were shown by Asthana (1997) in India and Joyasundara et al. (1999) in Bangladesh. Asthana and Jaysundra et al. reported that higher literacy of women affect the water consumption, source identification, quality and reliability and hence the WTP.

Engel et al. (2005) describe affordability of tariffs, knowledge on health gain from improved WSS, sensitivity to local customs and beliefs, ability of local people to operate and maintain, participation in design and management play important role for rural people to use improved WSS (Brookshire et al. 1993). The empirical studies show that income is not the sole factor for WTP for improved WSS at HH level. The income elasticity of demand has very low value for improved WSS. The characteristics of existing and improved system play significant role for statement of WTP. Studies show that income share of WTP varies from $0.5 \%$ to $10 \%$. Educational status and gender also have roles on determining demand and WTP. However the relation between gender and WTP is more contextual and location induced.

Wendimul and Bekele (2011) found the mean WTP for quality water supply is found to be $\$ 0.025$ per $20 \mathrm{~L}$ container which is well above the current tariff rate of $\$ 0.005$ per $20 \mathrm{~L}$ container charged by Oromiya regional government in Ethiopia. Ifabiyi (2011) found that household size had no bearings on the water demand of the study area. People with low educational status and low family size found to have consumed more water. Water consumption was controlled by economic factor and found not serious about environmental factor. Majority of the consumers were found WTP for improved services. Those who lost the confidence in water supply service system were found not willing to pay. It was found that people with regular water supply from public water supply system did not want private sector's involvement while with the opposite case the answer was yes. The first factor, Household Income Factor contributed 64.5\% explanation to the variance. The second factor contributed $22.4 \%$ explanation to the variance in the equation. It was interesting that, young respondents were to pay 
more for water in contrast to elder ones. Similarly, females were to pay more than male counter part. He also found that culture and tradition put some influence to these women. The third factor was educational variables with $11.3 \%$ contribution to the variance to explain the WTP Higher the educational level higher the WTP for water. He had again put some study works to defend his finding.

Wang et al., (2008) surveyed almost 1,500 HHs in five suburban districts in Chongqing Municipality and explained that significant increase in the water price is feasible as long as the poorest $\mathrm{HHs}$ can be properly subsidized and certain public awareness and accountability campaigns could be conducted to make the price increase more acceptable to public.Pour and Kalashami, (2012) found that $40 \%$ of urban respondents and $7 \%$ of rural respondents were satisfied with current supply system. On the other hand, 93\% rural and $60 \%$ urban respondents stated their dissatisfaction towards the quality of water. They found that consumers were willing to pay 6877 Rials per cubic meter of water in the study area.

Tarfasa (2013) in a study in Ethiopia found improvements in all the nonmonetary attributes were more likely to bring about a positive utility among the individuals hence more willing for improved system. But, $\mathrm{HH}$ demand less drinking water as the bill increases, as expected. Sex of the $\mathrm{HH}$ head, income, the area (zone) of living and HH's aversion behavior are the significant socio-demographic variables. Women prefer improvement in the domestic water supply compared to male $\mathrm{HH}$ heads. Higher the income more was WTP for proposed change. People with lowest income and lowest service found to pay up to 60 percent extra for improvement over the current bill for water. The significant effect was found for averting behavior and expenditures. Keeping the quality of water constant, it was found that supply of water increment results in the increase in WTP. The WTP was found to be USD 1.36 where no boiling is needed for drinking. In case of boiling needed only for infants WTP increases from 0 to USD 0.66 per month when supply increases per week by one day.

Awad and Hollander (2010) in study in Palestine concluded WTP for use values showed NIS 49.67 per month with standard deviation of 40.02 among the 525 samples. Whereas, mean WTP was 38.23 per month with 
standard deviation of NIS 30.71 for non-use values. From mean rank value it was revealed that numbers of respondents who are willing to pay are more than who are not willing to pay for improved WSS. The variable, water consumption, age, the income and the use of water filters and income have significant on WTP while consumption has a negative significant effect on WTP. Respondents from rural area shows not willing to pay for improved WSS while the urban respondents have insignificant impact on WTP. Other variables educational level, time period "how long the respondent has lived in the region?' employment status, gainfully employed "the family members who are gainfully employed" and household size have insignificant impact on WTP. The socioeconomic factors of income, age, gender, location, time period and employment status, are expected to be positive and have significant impact on WTP, which is evidence that the WTP amount is significant.

Engel et. al (2005) found that out-migration and water related disease are significant in terms of probability and education and $\mathrm{HH}$ income are explanatory factors for $\mathrm{HH}$ water demand and WTP and Volta basin of Ghana. It is assumed that involvement of people in planning decisions will will foster the efficiency and equity in community management of improved water resources.

In Nepal very few studies are carried out to measure the willingness to pay for improved water supply system for household use. No studies has been conducted to assess the factors affecting the willingness to pay for improved water supply system for household consumption in this area.

\section{Data and Methods}

It is generally believed that south facing hilly settlements generally have problem with water sources. So, at first Sabhung-Bhagwatipur VDC was selected purposively which lies in the rural part of Tanahu district of Nepal and lies in the southern part of the district. Ward number 5, 6, 7 and 8 are few of the many communities having problem in easier water supply system for drinking and $\mathrm{HH}$ consumptions purposes. The majority of water sources lie below the settlement area and hence people have to either go to source by themselves or use power to lift the water up 
hill and redistribute. The availability of water also differ according to the season and practice of water collection i.e. whether the source is open or covered or have collection tank with tapes etc. In some cases, water fetching seems to be not hygienic where water source is not covered and free human access to the water source point. Measuring willingness to pay by rural dwellers would provide a valuable reference for water supply policy and procedure. So, these wards were selected for this study. There are $252 \mathrm{HHs}$ in ward five, $273 \mathrm{HHs}$ in ward six, 95H ins in ward seven and $135 \mathrm{HHs}$ in ward eight. So, total study population for this research work is 755 households. From these households, 127 households ( at 5 percent margin of error and 5 percent level of significance) were proportionately distributed in wards 15, 6, 7 and 8 as 42, 46, 16 and 23 respectively. Then the information was collected from these households using structured questionnaire using interview technique. For the administration of questionnaire survey, head of the household or any other member was interviewed personally. However, respondent below 16 years of age was not considered for interview. Descriptive as well as inferential statistics have been used for the analysis. Descriptive statistics was used to find the frequency, percentage whereas Chi-square test was used to find the factors associated with willingness to pay for improved water supply system. For analysis of data, SPSS-16 was used.

\section{Results and Discussion}

Based on the data collected from 127 households, we have the following results and discussion.

\section{Willingness to pay for improved water supply}

Willingness to pay for improved water supply system in relation to individual and household characteristics was examined to find the association. In this context, association of Willingness to pay for improved water supply system in relation to individual and household characteristics (sex of respondent, head of the household, $\mathrm{HH}$ size, age, income, literacy status, foreign employment (family receiving remittance), land ownership, ownership of kitchen garden) was examined (table 1). 
Table 1

Association between willingness to pay for improved water supply system and selected background characteristics

\begin{tabular}{|c|c|c|c|c|}
\hline \multirow{2}{*}{ Characteristics } & \multicolumn{2}{|c|}{ Willingness to Pay } & \multirow{2}{*}{$\begin{array}{l}\text { Total } \\
\text { \% (n) }\end{array}$} & \multirow{2}{*}{$\begin{array}{l}\text { p-value based on } \\
\text { Chi Square test }\end{array}$} \\
\hline & Yes \% (n) & No \% (n) & & \\
\hline \multicolumn{5}{|l|}{ Sex of the the respondent } \\
\hline Male & $52(66)$ & $7.9(10)$ & $59.8(76)$ & \\
\hline Female & $30.7(39)$ & $9.4(12)$ & $40.2(51)$ & 0.130 \\
\hline \multicolumn{5}{|l|}{ Age of the respondent (year) } \\
\hline Below 40 & $36.2(46)$ & $6.3(8)$ & $42.5(54)$ & \\
\hline Above 40 & $46.5(59)$ & $11(14)$ & $57.5(73)$ & 0.521 \\
\hline \multicolumn{5}{|l|}{ Literacy } \\
\hline Illiterate & $18.9(24)$ & $2.4(3)$ & 21.2(27) & \\
\hline Literate & $63.8(81)$ & 15(19) & $78.7(100)$ & 0.336 \\
\hline \multicolumn{5}{|l|}{ Head of the household } \\
\hline Male & 76.4(97) & $14.2(18)$ & $90.6(115)$ & \\
\hline Female & $6.3(8)$ & $3.1(4)$ & $9.4(12)$ & 0.124 \\
\hline \multicolumn{5}{|l|}{ Household income } \\
\hline Less or equal to Rs. 10,000 & $30.6(38)$ & $5.6(7)$ & $36.3(45)$ & \\
\hline More than Rs. 10,000 & $52.4(65)$ & $11.3(14)$ & $63.7(79)$ & 0.757 \\
\hline \multicolumn{5}{|l|}{ Family size } \\
\hline Average (less or equal to 5) & $55.1(70)$ & $12.6(16)$ & $67.7(86)$ & \\
\hline Large (More than 5) & $27.6(35)$ & $4.7(6)$ & $32.3(41)$ & 0.580 \\
\hline \multicolumn{5}{|l|}{ Land ownership } \\
\hline Less or equal to 10 Ropani & 7.1(9) & $1.6(2)$ & $8.7(11)$ & \\
\hline More than 10 Ropani & $75.6(96)$ & $15.7(20)$ & $91.3(116)$ & 0.937 \\
\hline \multicolumn{5}{|l|}{ HH receiving remittance } \\
\hline Yes & $52.8(67)$ & $12.6(16)$ & $65.4(83)$ & \\
\hline No & $29.9(38)$ & $4.7(6)$ & $34.6(44)$ & 0.424 \\
\hline \multicolumn{5}{|l|}{ Have kitchen garden in $\mathrm{HH}$} \\
\hline Yes & $73.2(93)$ & 15(19) & $88.2(112)$ & \\
\hline No & $9.4(12)$ & $2.4(3)$ & $11.8(15)$ & 0.770 \\
\hline
\end{tabular}

Source: Field Survey, 2015

It is found that sex of the respondents, head of the household, $\mathrm{HH}$ size, age, income, literacy status, foreign employment (family receiving remittance), land ownership, ownership of kitchen garden do not show any statistically significant relationship with one's WTP for improved WSS. This result is inconsistent with results from Ifabiyi (2011), Wang et al. (2008) and Awad 
and Hollander (2011) where it was found that WTP is significantly associated with $\mathrm{HH}$ size, $\mathrm{HH}$ income, Age \& Sex of respondent and educational status. It may be due to the homogeneous characteristics of the households.

Water-related factors associated with willingness to pay for improved water supply system

Here, willingness to pay for improved water supply system in response to water management as well as water-born diseases was examined to find the association. At first, association of WTP for improved water supply system in response to water management(Single/Multiple Water Source, users' satisfaction, want for change, water fetching time, and $\mathrm{HH}$ level water purification practices) was examined (table 2). Then association of WTP for improved water supply system in response to water-born diseases (Suffered from diarrhea, dysentery, seasonal flu, Jaundice, worm and dental pain) was examined (table 3).

\section{Table 2}

Association between willingness to pay for improved water supply system and selected water related factors

\begin{tabular}{|c|c|c|c|c|}
\hline \multirow{2}{*}{ Characteristics } & \multicolumn{2}{|c|}{ Willingness to Pay } & \multirow{2}{*}{ Total } & \multirow{2}{*}{$\begin{array}{l}p \text {-value based } \\
\text { on Chi S quare }\end{array}$} \\
\hline & Yes (\%) & No (\%) & & \\
\hline \multicolumn{5}{|c|}{ Water source for HH consumption } \\
\hline Single Source & $20.5(26)$ & $10.2(13)$ & 30.7 (39) & \\
\hline Multiple Source & $62.2(79)$ & $7.1(9)$ & $69.3(88)$ & 0.002 \\
\hline \multicolumn{5}{|c|}{ Satisfaction from activities of WUC } \\
\hline Yes & $63.7(53)$ & $25.3(21)$ & $89.2(74)$ & \\
\hline No & $10.8(9)$ & $0(0)$ & $10.8(9)$ & 0.064 \\
\hline \multicolumn{5}{|l|}{ Satisfied by water quantity } \\
\hline Yes & $46.5(59)$ & $17.3(22)$ & $63.8(81)$ & \\
\hline No & $36.2(46)$ & $0(0)$ & $36.2(46)$ & 0.001 \\
\hline \multicolumn{5}{|l|}{ Want for change in current WSS } \\
\hline Want Change & $82.7(105)$ & $0.8(1)$ & $83.5(106)$ & \\
\hline Its OK & $0(0)$ & $16.5(21)$ & $16.5(21)$ & 0.001 \\
\hline \multicolumn{5}{|c|}{ Time to fetch water (1 Round Trip) } \\
\hline Equal or less than 15 Minutes & $42.5(54)$ & $17.3(22)$ & $59.8(76)$ & \\
\hline More than 15 Minutes & $40.2(51)$ & $0(0)$ & $40.2(51)$ & 0.001 \\
\hline \multicolumn{5}{|c|}{ Water purification before drinking } \\
\hline Yes & $59.8(76)$ & $10.2(13)$ & $70.1(89)$ & \\
\hline No & $22.8(29)$ & $7.1(9)$ & $29.9(38)$ & 0.216 \\
\hline
\end{tabular}

Source: Field Survey, 2015 
Table 3

Association between willingness to pay for improved water supply system and incidence of water-borne diseases

\begin{tabular}{|c|c|c|c|}
\hline \multirow[t]{2}{*}{ Characteristics } & Willingness to Pay & \multirow[t]{2}{*}{ Total } & \multirow{2}{*}{$\begin{array}{l}\text { p-value based } \\
\text { on Chi Square }\end{array}$} \\
\hline & No (\%) & & \\
\hline \multicolumn{4}{|c|}{$\begin{array}{l}\text { HH member suffered from } \\
\text { diarrhea }\end{array}$} \\
\hline Yes & $7.1(9)$ & $25.2(32)$ & \\
\hline No & $10.2(13)$ & $74.8(95)$ & 0.062 \\
\hline \multicolumn{4}{|c|}{ dysentery } \\
\hline Yes & $2.4(3)$ & $14.2(18)$ & \\
\hline No & $15(19)$ & $85.8(109)$ & 0.937 \\
\hline \multicolumn{4}{|c|}{ HH member suffered from flu } \\
\hline Yes & $10.2(13)$ & $70.9(90)$ & \\
\hline No & $7(9)$ & $29.1(37)$ & 0.181 \\
\hline $\begin{array}{l}\text { HH member } \\
\text { worm }\end{array}$ & \multicolumn{3}{|c|}{ worm } \\
\hline Yes & $3.9(5)$ & $21.3(27)$ & \\
\hline No & $13.4(17)$ & $78.7(100)$ & 0.853 \\
\hline $\begin{array}{l}\text { HH member } \\
\text { jaundice }\end{array}$ & & & \\
\hline Yes & $5.5(7)$ & $16.5(21)$ & \\
\hline No & $11.8(15)$ & $83.5(106)$ & 0.034 \\
\hline \multicolumn{4}{|c|}{$\begin{array}{l}\text { HH member suffered by dental } \\
\text { pain }\end{array}$} \\
\hline Yes & $2.4(3)$ & $37.8(48)$ & \\
\hline No & $15(19)$ & $62.2(79)$ & 0.010 \\
\hline
\end{tabular}

Source: Field Survey, 2015.

Water source $(p<0.01)$, dental pain $(p<0.01)$, water quantity $(p<0.01)$, want for change $(p<0.01)$, water fetching time $(p<0.01)$, and cases of Jaundice $(p<0.05)$ are significantly associated with one's willingness to pay for improved water supply system. This result is consistent with the results from Pattanayek et al. (2006), Tarfasa (2013) and Awad and Hollander (2010) where it was found that satisfaction with current WSS, Health consciousness, institutional factor, quantity of water, participatory planning have significant association with WTP for improved WSS.

However, there is no significant association of willingness to pay with satisfaction from WUC activities, water purification, diarrhea, dysentery, seasonal flu, and suffering from worm. So, water source, dental pain, water 
quantity, want for change, water fetching time, and cases of Jaundice are the factors affecting willingness to pay for improved water supply system.

\section{Conclusion}

This study highlights that there is no significant association between social demographic and economic characteristics (sex of respondent; head of the household, $\mathrm{HH}$ size, age, income, literacy status, foreign employment (family receiving remittance), land ownership, ownership of kitchen garden) with one's willingness to pay for improved water supply system, i.e. do not have significant association with willingness to pay. However, water source $(p<0.01)$, dental Pain $(p<0.01)$, water quantity $(p<0.01)$, want for change $(p<0.01)$, water fetching time $(p<0.01)$, and cases of Jaundice $(p<0.05)$ are significantly associated with one's willingness to pay for improved water supply system. However, there is no significant association of willingness to pay with satisfaction from WUC activities, water purification, diarrhea, dysentery, seasonal flu, and suffering from worm. Hence it is concluded that water source, dental pain, water quantity, want for change, water fetching time, and cases of Jaundice are the factors affecting willingness to pay for improved water supply system.

\section{References}

Adeoye, P.A., Adeoulu, A.R. \& Ibrahim, H.M. (2013). Appraisal of rural water supply: Case study of Kwara State, North Central Nigeria. International Journal of Basic and Applied Science, 1(4):816 - 826.

Asthana, A.N. (1997). Where the water is free but the bucket are empty: demand analyses of drinking water in rural India. Open Economies Review, 8:137-149.

Awad, I., \& Hollander, R. (2010). Applying contingent valuation method to measure the total economic value of domestic water services: A Case study in Ramallah Governorate, Palestine. European Journal of Economics, Finance and Administrative Sciences, 20: 77-91.

Bhandari, B., \& Grant, M. (2007). User satisfaction and sustainability of drinking water schemes in rural communities of Nepal. 
Sustainability: Science, Practice, \& Policy, 3 (1):12-19. [http:// ejournal.nbii.org]

Brookshire, D. \& Whittington, D. (1993). Water resources issues in the developing countries. Water Resources Research, I:1883- 1888.

Engel, S., Iskandarani, M., \& Useche, M. (2005). Improved water supply in Ghanian Volta Basin: Who uses it and who participates in community decision-making? International Food Policy Researh Institute, Environment and Production Technogloyg Division. EPT Discussion Paper 129.

Gunatilake, H., \& Tachiiri, M. (2012). Willingness to pay and inclusive tariff designs for improved water supply services in Khulna, Bangladesh. ADB South Asia working paper series, no. 9. p 25. Asian Development Bank.

Ifabiyi, I.P. (2011).Willingness to pay for water at household level in Ilorin, Kwara State, Nigeria. Global Journal of Human Social Science, 11: 15-24.

Lammerink, M. (1998). Community managed rural water supply: experiences from participatory action research in Kenya, Cameroon, Nepal, Pakistan, Guatemala and Colombia. Community Development Journal, 33(4):342-352.

Pattanayak, S.K., Berg, C., Yang, J., \& Houtven, G.V. (2006). The use of willingness to pay experiments: estimating demand for piped water connections in Sri Lanka. World Bank Policy Research Working Paper, 3818.

Pour, M. T. \& Kalashami, M. K., (2012). Applying CVM for Economic Valuation of Drinking Water in Iran. International Journal of Agricultural Management and Development (IJAMAD), 2(3): 209-214[http:// www.ijamad.com].

Tarfasa, S. (2013). How much are households willing to contribute to the cost recovery of drinking water supply? Results from a household survey. Drinking Water: Engineering and Science, 6: 33-38.

Wang, H., Xie, J. \& Li, H. (2008). Domestic Water Pricing With Household Surveys: A Study of Acceptabiity and Willingness to Pay in 
Chongqing, China. The World Bank, Development Research Group Sustainable Rural and Urban Development Team.

WBWDRT (World Bank Water Demand Research Team) (1993). The demand for water in rural areas determinants and policy implications. World Bank Research Observer, 18(1): 47-70.

Wendimul, S. \& Bekele, W. (2011). Determinants of individual willingness to pay for quality water supply: The case of Wonji Shoa Sugar Estate, Ethiopia. Journal of Ecology and the Natural Environment, 3(15): 474-480.

Whittington, D., Davis J., \& McClelland, E. (1998). Implementing a demanddriven approach to community water supply planning: a case study of Lugazi, Kenya. Water International, 23(3):134-145.

WHO (World Health Organization) \& UNICEF (United Nations Children's Fund)(2006). Joint monitoring programme 2006. Meeting the MDG9 drinking water and sanitation target: the urban and rural challenge of the decade. New York. UNICEF, Geneva.

World Bank Groups Program for Water Supply and Sanitation Report (2004). Water Supply and Sanitation Sector Board, 6-8 